\title{
OVERVIEW OF DESIGN TEACHING ON ENGINEERING COURSES: A COMPARATIVE STUDY BETWEEN BRAZIL AND PORTUGAL
}

\author{
Claudia Alquezar Facca ${ }^{1}$, Jorge Lino Alves ${ }^{2}$, \& Ana Mae Barbosa ${ }^{3}$ \\ ${ }^{1}$ Engineering School, Mauá Institute of Technology (Brazil); PPG Design, Anhembi Morumbi University \\ (Brazil); Faculty of Engineering, University of Porto (Portugal) \\ ${ }^{2}$ INEGI, Faculty of Engineering, University of Porto (Portugal) \\ ${ }^{3} P P G$ Design, Anhembi Morumbi University (Brazil)
}

\begin{abstract}
This paper presents an overview of design teaching in the undergraduate engineering courses at the main institutions of higher education in Brazil and Portugal. In order to carry out the comparative study, the curricula of the main engineering courses in Brazil and Portugal were used. The aim of the research is to first analyze how the design, as a disciplinary content, is being introduced in the engineering courses in both countries. In a second moment, a comparative analysis will be made between the information collected in Brazil and in Portugal in order to register how this conjugation is occurring and whether there is some similarity or not in the way of design approach in the engineering courses in each country. As a result, it is discussed how the design can collaborate with the interdisciplinarity between these areas and contribute with the formation of the new competences of the engineer.
\end{abstract}

Keywords: Education, design, engineering, Brazil, Portugal.

\section{Introduction}

Education is the object of study, concern, focus, strategy and discussion in all the nations of the globe and reflects the intense changes the world has witnessed in the last decades of the $20^{\text {th }}$ century, beginning with the two great wars, then the expansion of capitalism and the cultural and economic globalization in the $21^{\text {th }}$ century. According to UNESCO (2010), engineering deserves our attention, its contribution to development must be fully acknowledged, being vital the full measurement of engineering's capacity to make a difference in the developing world. If engineering's role is more visible and better understood, more people would be attracted to it as a career. Now and in the years to come, it is fundamental to ensure that motivated young women and men concerned about problems in the developing world continue to enter the field in enough numbers.

The performance of engineering professionals is closely associated with the improvement of products and processes, optimization and innovation of production management models and Research \& Development (R\&D) efforts of the companies. The conditions of the engineering education occupy, therefore, a central place in the discussions involving the formulation and implementation of strategies for industrial development. They are part of the range of challenges that countries must face to sustain productivity gains and to strengthen their competitive positions in the dynamic knowledge-based economy of the world. The economic growth should be accompanied by a qualitative and quantitative improvement of employment and greater social cohesion. This demands a change in higher education system, promoting interdisciplinarity, stimulating entrepreneurship, emphasizing the cultural and social involvement of universities. This is propelled by strategic government investment in engineering education as an incubator for the technology-based entrepreneurial talent that will drive national economic growth (Brasil, 2019; Confederação Nacional da Indústria [CNI], 2018; Cordeiro et al, 2008, Heitor et al, 2004).

\section{Scenario of engineering education in Brazil}

Portuguese and Brazilian relations have lasted more than five centuries. Having as a backdrop the Atlantic, the two "brothers" countries are physically and symbolically united, by territory, history, culture, language and regional spaces in which they are inserted. Some points of convergence and singularities are evidenced, as well as the strong distinction regarding the amplitude of difficulties, since in Brazil these are extended by their territorial dimension, socioeconomic inequalities and regional diversities (Almeida, 2008). 
Engineering education in Brazil had its beginning in 1699, with Dom Pedro II, King of Portugal at the time, and the creation of the first class of Fortification, for the training of military engineers. The fundamental landmark for higher education was the coming of the Portuguese royal family to Brazil in 1808, a fact that allowed the creation of several institutions, some of them offering higher education courses. The beginning of the formal education of engineering in Brazil was with the Royal Military Academy in 1810, replacing the Royal Academy of Artillery, Fortification and Drawing, installed in 1792, in Rio de Janeiro. In 1874, the army left the formation of engineers for civil institutions, when the first engineering school was borne: The Polytechnic School of Largo de São Francisco. Throughout the $19^{\text {th }}$ century, several educational establishments for higher level vocational training emerged, even though they were isolated and in specific contexts, without having a university system, such as the Polytechnic School of São Paulo in 1893. The first university of the federal government of Brazil, the current Federal University of Rio de Janeiro (UFRJ), was created in 1920. And in 1934, through the political perspective of a liberal-democratic regime, with a different model, the University of São Paulo was created by the São Paulo government. Since 1950 there was a significant growth in the number of courses of engineering, with the great expansion occurred from the second half of the 90's. This is coincident with the edition of the new "Law of Guidelines and Bases of National Education" (1996), when the growth of engineering courses has reached an annual average of 96 new courses per year, mainly in the private sector (Cordeiro et al, 2008).

From 2010 to 2014, due mainly to the performance of the country in terms of infrastructures expansion, a significant growth was registered, both in terms of the offers (expansion of the number of courses), and applications for engineering courses (Brasil, 2019; CNI, 2018). After this period, these numbers started to decrease due to the recent economic, political and social crisis installed in the country. For each 1,000 candidates in engineering selection processes, only 175 were admitted and only 95 concluded their courses, suggesting a kind of "funnel" (CNI, 2018). In 2018, 6,106 engineering courses were registered in the E-MEC system, operating in 1,176 distinct institutions, including private and public. In addition to the numerical expansion, there was also a great growth of qualifications or areas of coverage of the engineering courses. Today there are already 60, considering the first denomination of the courses (civil, electrical, mechanics, etc.) and more than 250 when is considered the second denomination or emphasis (civil construction, electrical power, automobile mechanics, etc.). Between 2001 and 2018, there was, therefore, a total growth of $692 \%$ in the number of engineering courses (Brasil, 2019).

Brazil faces some difficulties to compete in the international market. According to the Global Innovation Index (IGI), the country lost 22 positions in the ranking between 2011 and 2017, which stood at $69^{\circ}$ place among the 128 countries evaluated. In 2014, while Portugal had about 16 engineers for each 10,000 inhabitants, Brazil recorded only 4.8 engineers for the same inhabitants (Brasil, 2019).

\section{Scenario of engineering education in Portugal}

The teaching of engineering in Portugal was originated in the Nautical Class, created in 1765 . The Royal Academy of Fortification, Artillery and Drawing, created in 1790, is considered the first modern school of Portuguese engineering and one of the first in the world. In the $20^{\text {th }}$ century, with the implantation of the Republic in 1910, the teaching of engineering started for the first time to be held at the university, when the Polytechnic Academy of Porto, created in 1837, and predominantly military (although it also included civil engineering), replaced the School of Nautical. Integrated in the new University of Porto, created in 1911, with its courses of engineering, is in the genesis of the current Faculty of Engineering of that university (Azevedo, 2013). The foundation of Instituto Superior Técnico (1911) and the transformation of the Polytechnic Academy of Porto into Technical Faculty (1915), were considered decisive milestones in the technical context, since they would play a fundamental role in consolidating the social recognition of knowledge (Heitor et al, 2004).

In 1970, the Polytechnic Institutes were integrated into the higher education system, attributing the bachelor's degree (Academia de Engenharia de Portugal [AEP], 2006). Since 1972, new university engineering courses have been created in Coimbra, Porto, Braga, Aveiro, Lisbon and some other localities, strengthened by the European integration. The law of bases of the educational system integrated the higher institutes of engineering in Polytechnic education in 1988 (AEP, 2006, Heitor et al, 2004). Currently, the teaching of engineering is carried out in universities (oriented to the research and creation of scientific and cultural knowledge) and polytechnic institutes (oriented to the applied research and creation of the knowledge of professional nature), both public and private (Azevedo, 2013), which integrate an intrinsically rich and diversified institutional system.

Considering the area of education and training represented by Engineering, Manufacturing and Construction, currently Portugal has 319 courses in 94 institutions and organic units of education, including the graduation and integrated masters, in 12 specialties (Ordem dos Engenheiros, 2015). These specialties are subdivided in 72 different qualifications or areas of coverage of the engineering, in a total of 1010 cycles of study, that offered in 2018, 11,615 places, occupied by 10,805 selected students through the 3 stages of admission. Regarding the number of students, there was an increase of almost $9 \%$ in the total number of 
graduates in higher education in engineering (from 14,412 in 2010 to 16,105 in 2017), which opposes to the decrease of $12.4 \%$ in the total number of students enrolled in this area (from 88,644 in 2010 to 78,830 in 2018) (DGES, 2019).

The Bologna Process has triggered an impressive set of reforms (AEP, 2006; Heitor et al, 2004). Signed in 1999, is an intergovernmental cooperation of 48 European countries in the field of higher education that guides the collective effort on how to improve the internationalization of higher education (European Commission, n.d.). Furthermore, there is still the Erasmus+, the European Union's programme to support education, training, youth and sport in Europe, providing opportunities for Europeans to study, train, and gain experience abroad (European Commission, n.d.).

While Brazil occupies the $40^{\text {th }}$ place, Portugal is classified as the $25^{\text {th }}$ best higher education system in the world in the U21 Rankings of National Higher Education Systems 2019, developed by "Universitas 21", a reference network that aggregates universities research in several countries (Universitas 21, 2019).

\section{Comparative study between Brazil and Portugal}

Despite the visible growth of admissions in engineering, the productive sector has encountered difficulties to recruit skilled workers to act on the frontier of knowledge of engineering, which, in addition to the technique, requires that its professionals have mastery of skills as leadership, work in group, planning, strategic management and learning autonomously. These competencies, known as "soft skills", combine solid technical training with a more humanistic and entrepreneurial formation (Brasil, 2019). Proposals for modernizing engineering courses should consider international trends and specific aspects of the reality of each country, with more multidisciplinary, systemic and consistent visions. All these aspects should be aligned with the needs of society, especially in relation to sustainability issues, future-bearing areas (e.g. Nanobiotechnology) and new generation of production 4.0 industry (e.g. advanced automation, big data, artificial intelligence, design, etc.). In international experiences, the curricula focused on the development of competencies and the adoption of more practice-oriented teaching methodologies, such as the PBL - Project Based Learning, are good examples of modernization (CNI, 2018). Engineering knowledge has always been system-based knowledge where engineers are working with the phenomena of black boxes in their design. The new challenge is not to work with the black boxes, but to do work within a collaborative intercultural and interdisciplinary team (UNESCO, 2010).

Design projects that have been used as vehicles to motivate and integrate learning and cornerstone project-based courses, are also seen to enhance students' motivation and their attraction to engineering. So, what does the word "design" mean in an engineering context? Why is this complex, fascinating subject so hard to teach? Engineering design is a systematic, intelligent process in which designers generate, evaluate, and specify concepts for devices, systems, or processes whose form and function achieve clients' objectives or users' needs while satisfying a specified set of constraints (Dym, 2005). Design, interdisciplinary by nature, is a strategic problem-solving process that drives innovation, builds the business success and leads to better quality of life through innovative products, systems, services and experiences (World Design Organization [WDO], 2019).

Design can help and, through its tools and methodologies, show new paths inspired not only in new technologies, but also in human needs, adding new values that are perceived by consumers and viable to implement. By its holistic and integrative character, the design has become more valued and coined with the term "Design Thinking" establishing the correspondence between human needs (desirability) and the technical resources available (feasibility) considering the practical constraints of the business (viability) (Brown, 2009).

The design insertion format in engineering courses can be done in a variety of ways: as a programmatic content addressed within a discipline, as a regular compulsory subject, as an elective or optional subject, as an extension course, as a specialization or minor and, even, as a content linked to an integrated project. And there are two important aspects to introducing product design to engineering students at undergraduate level: "when" and "how" the subject of design is taught (Sathikh, 2018). When means that it could be introduced at the freshman year, making design a core subject at the very early stages of study, where the subject maybe introduced too early to be effective or as an elective, at the senior year, as a follow up to what students learn in the freshman year, maybe too late to bring some real effect. How is about the method and means that it can be taught not only with a principal focus based on the aesthetic but also upon usability, sustainability and design for manufacture (built on the framework of studio-based learning) (Mills; Treagust, 2003-04).

The aim of the research was to analyze how the design, as a subject content, is being introduced in the engineering courses in both countries. The curricula and teaching plans of Mechanical Engineering courses in important educational institutions in Brazil and Portugal were considered and selected among the best evaluated in 2018/2019, according to Quacquarelli Symonds [QS] World University Rankings by Subject 2019: Engineering - Mechanical, Aeronautical \& Manufacturing and the University Ranking of Folha de São Paulo (RUF 2018) - Mechanical Engineering. 
Table 1. Design subjects inserted in engineering courses in Brazil and Portugal (adapted by the authors, 2019).

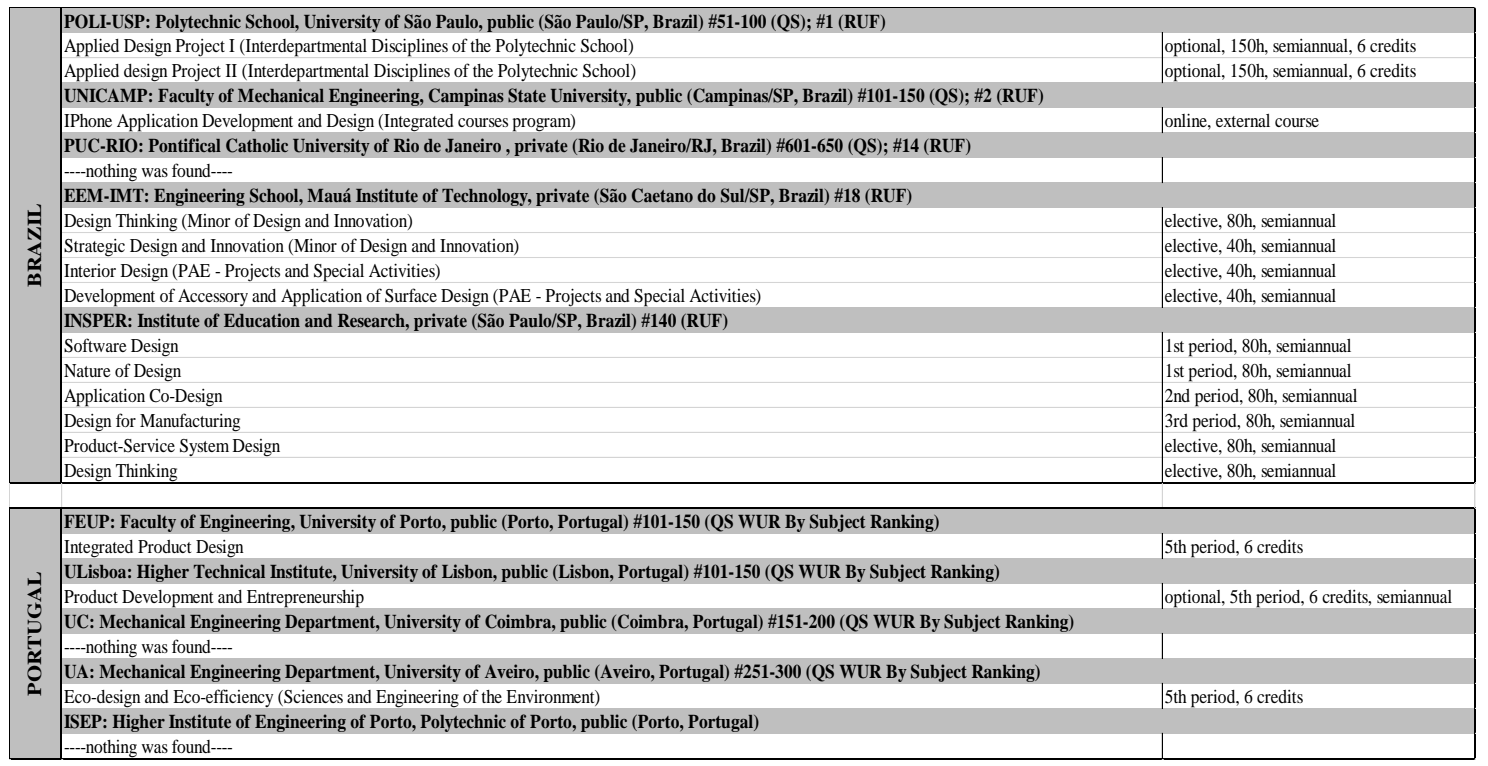

According to the collected data (Table 1), it can be observed that, in general, design as a subject is being inserted in mechanical engineering courses more prominently in Brazil, with the occurrence of 13 disciplines, comparing to Portugal, with the discreet occurrence of only 3 cases. In the majority (77\%) they are being offered as elective or optional, taken usually at the end of the course, in the last $\left(5^{\text {th }}\right)$ period. Other important observation is about the addressed content, where most of them are about project and product/service development.

Although this study was limited to a small sample, restricted to some institutions in Brazil and Portugal, have emerged during the research other schools in Europe that also offer design subjects in the mechanical engineering curriculum, such as: University of Cambridge, England (Structural Design, Product Design, Engineering Design, Integrated Design Project); Delft University of Technology, Netherlands (Machine Design Project); Politecnico di Milano, Italy (Machine Design); among others.

\section{Final considerations}

Design education represents both serious challenges and glorious opportunities (Dym, 2005). Design is still a complement to the engineer's training, and not a basic requirement; it is a start, but it still has a long way to go. In this scenario, design can act and show new paths, through its tools and methodologies, inspired in human needs, not only in new technologies, but also in adding new values that are perceived by consumers and are viable to implement. Design can then be considered as an interdisciplinary content factor that, when applied in design practice, can contribute to the development of innovative products, enrich the training of the engineer and be a relevant agent in the innovation of higher education.

\section{Acknowledgments}

This study was financed in part by CAPES (Coordenação de Aperfeiçoamento de Pessoal de Nível Superior) Brazil, Finance Code 001.

\section{References}

Academia de Engenharia de Portugal - AEP. (2006). O Ensino da Engenharia em Portugal. Relatório Final [The teaching of engineering in Portugal. Final Report]. Retrieved on April $20^{\text {th }}$, 2019, from https://tinyurl.com/y4r82c5n

Almeida, M. E. B (2008). Educação e tecnologias no Brasil e em Portugal em três momentos de sua história [Education and technologies in Brazil and Portugal in three moments of its history]. Educação, Formação \& Tecnologias; vol.1(1), pp. 23-36. Retrieved on April 22 ${ }^{\text {nd }}, 2019$, from http://eft.educom.pt. 
Azevedo, S. F. De. (2013). Da Academia Polytechnica de 1837 à Faculdade de Engenharia de Hoje, 176 anos de estudos superiores de engenharia no Porto [From 1837 Polytechnica Academy to the Faculty of Engineering today, 176 years of superior engineering studies in Porto]. Newsletter SPEE $\mathrm{n}^{\mathrm{o}} 5$, February 2012, Reissued in January $14^{\text {th }}$, 2013. Retrieved on April $23^{\text {rd }}$, 2019, from https://tinyurl.com/y2fm48n7.

Brasil. (2019). Ministério da Educação / Conselho Nacional de Educação - MEC/CNE. Diretrizes Curriculares Nacionais do Curso de Graduação em Engenharia [National Curriculum Guidelines of the Undergraduate Course in Engineering]. Parecer CNE/CES N : 1/2019, published in the Official Diary of the Union on $23^{\text {rd }}$ April, 2019. Retrieved on April $27^{\text {th }}$, 2019, from https://tinyurl.com/y358gf9p.

Brown, T. (2009). Change by Design: How Design Thinking Transforms Organizations and Inspires Innovation. New York: HarperBusiness.

Confederação Nacional da Indústria - CNI. (2018). Ensino de engenharia: fortalecimento e modernização. Propostas da indústria para as eleições [Engineering Teaching: strengthening and modernization. Industry proposals for elections]. Brasília. 32 p.: il. v. 7. Retrieved on April 22 ${ }^{\text {nd }}$, 2019, from https://tinyurl.com/y44zcopq.

Cordeiro, J. S.; Almeida, N. N.; Borges, M. N.; Dutra, S.C.; Valinote, O.L.; Pravia, Z.M.C. (2008). Um Futuro para a Educação em Engenharia no Brasil: Desafios e Oportunidades [A Future for Engineering Education in Brazil: Challenges and Opportunities]. Revista de Ensino de Engenharia, v. 27, n. 3, p. 69-82, Special edition 2008. Retrieved on April 27 , 2019, from https://tinyurl.com/y4f3ovco.

Direção Geral do Ensino Superior - DGES. (2019). Pesquisa de Cursos e Instituições [Courses and Institutions Research]. Retrieved on April $24^{\text {th }}, 2019$, from https://tinyurl.com/y42awvp9.

Dym, C. L. (2005). Engineering Design Thinking, Teaching, and Learning. Journal of Engineering Education. Retrieved on April $24^{\text {th }}, 2019$, from https://tinyurl.com/y2vkwqld.

European Commission. (n.d.). Education \& Training. Retrieved on April 23 ${ }^{\text {rd }}$, 2019, from https://tinyurl.com/y67ebnkx.

Folha University Ranking - RUF. (2018). Course Rankings: Mechanical Engineering. Folha de S. Paulo. Retrieved on April 29 , 2019, from https://tinyurl.com/y2ho3b2m.

Heitor, M.; Horta, H.; Conceição, P. (2004). Do ensino técnico ao ensino das ciências de engenharia: uma leitura sobre a evolução do ensino de engenharia em Portugal no século XX [From technical education to teaching of engineering sciences: a reading on the evolution of engineering education in Portugal in the $20^{\text {th }}$ century]. In Heitor, M.; Brito, J. M. B. De; Rollo, M. F. (coords.). Momentos de Inovação e Engenharia em Portugal no século XX [Moments of Innovation and Engineering in Portugal in the 20th century]. Vol. 1. Lisbon: Don Quixote.

Mills, J. E.; Treagust, D. F. (2003-04). Engineering Education - Is Problem based or Project-Based Learning the Answer? Australasian Journal of Engineering Education, online publication. Retrieved on April 30 ${ }^{\text {th }}, 2019$ from https://tinyurl.com/y28ssvb5.

Ordem dos Engenheiros. (2015). Atos de Engenharia por Especialidade da Ordem dos Engenheiros [Engineering Acts by Specialty of the Order of Engineers]. Regulamento n. ${ }^{\circ}$ 420/2015. Conselho Diretivo Nacional. Diário da República, 2. ${ }^{a}$ série — N. ${ }^{\circ}$ 139, 20 de julho de 2015. Retrieved on April $24^{\text {th }}, 2019$, from https://tinyurl.com/j2pltj2.

Quacquarelli Symonds - QS. (2019). World University Rankings by Subject 2019: Engineering Mechanical, Aeronautical \& Manufacturing. QS Top Universities. Retrieved on April 29 ${ }^{\text {th }}, 2019$, from https://tinyurl.com/y6rzan2r.

Sathikh, P. M. (2018). Approaches to Teaching Product Design to Engineering Students. International Conference on Engineering and Product Design Education. 6-7 September 2018, Dyson School of Design Engineering, Imperial College, London, United Kingdom. Retrieved on April 30 ${ }^{\text {th }}, 2019$, from https://tinyurl.com/y3bv724n.

United Nations Education, Scientific and Cultural Organization - UNESCO. (2010). UNESCO Report. Engineering: Issues, Challenges and Opportunities for Development. France, UNESCO Publishing. Retrieved on April 22 $2^{\text {nd }}$, 2019, from https://tinyurl.com/y46as56m.

Universitas 21. (2019). The Network. U21 Rankings. Retrieved on April 23 ${ }^{\text {rd }}$, 2019, from https://tinyurl.com/y4mcft4r.

World Design Organization - WDO. (2019). Definition of Industrial Design. Retrieved on April 29 ${ }^{\text {th }}, 2019$, from https://tinyurl.com/y2obeh67. 